Review

\title{
Emerging Therapeutic Potential of Nanoparticles in Pancreatic Cancer: A Systematic Review of Clinical Trials
}

\author{
Minnie $\mathrm{Au}{ }^{1,2,+}$, Theophilus I. Emeto ${ }^{1, *, \dagger}$, Jacinta Power ${ }^{2}$, Venkat N. Vangaveti ${ }^{3}$ and \\ Hock C. Lai ${ }^{2}$ \\ 1 Public Health and Tropical Medicine, College of Public Health, Medical and Veterinary Sciences, \\ James Cook University, James Cook Drive, Douglas, Townsville QLD 4811, Australia; \\ Minnie.au@my.jcu.edu.au \\ 2 Townsville Cancer Centre, The Townsville Hospital, Townsville QLD 4814, Australia; \\ Jacinta.power@my.jcu.edu.au (J.P.); Hock.Lai@health.qld.gov.au (H.C.L.) \\ 3 College of Medicine and Dentistry, James Cook University, James Cook Drive, \\ Douglas, Townsville QLD 4811, Australia; venkat.vangaveti@jcu.edu.au \\ * Correspondence: Theophilus.emeto@jcu.edu.au; Tel.: +61-74781-5082 \\ + These authors contributed equally to this work.
}

Academic Editor: Shaker A. Mousa

Received: 15 June 2016; Accepted: 16 August 2016; Published: 19 August 2016

\begin{abstract}
Pancreatic cancer is an aggressive disease with a five year survival rate of less than $5 \%$, which is associated with late presentation. In recent years, research into nanomedicine and the use of nanoparticles as therapeutic agents for cancers has increased. This article describes the latest developments in the use of nanoparticles, and evaluates the risks and benefits of nanoparticles as an emerging therapy for pancreatic cancer. The Preferred Reporting Items of Systematic Reviews and Meta-Analyses checklist was used. Studies were extracted by searching the Embase, MEDLINE, SCOPUS, Web of Science, and Cochrane Library databases from inception to 18 March 2016 with no language restrictions. Clinical trials involving the use of nanoparticles as a therapeutic or prognostic option in patients with pancreatic cancer were considered. Selected studies were evaluated using the Jadad score for randomised control trials and the Therapy CA Worksheet for intervention studies. Of the 210 articles found, 10 clinical trials including one randomised control trial and nine phase I/II clinical trials met the inclusion criteria and were analysed. These studies demonstrated that nanoparticles can be used in conjunction with chemotherapeutic agents increasing their efficacy whilst reducing their toxicity. Increased efficacy of treatment with nanoparticles may improve the clinical outcomes and quality of life in patients with pancreatic cancer, although the long-term side effects are yet to be defined. The study registration number is CRD42015020009.
\end{abstract}

Keywords: pancreatic cancer; nanoparticles; clinical trials; cancer therapy

\section{Introduction}

Pancreatic cancer is a rare but aggressive disease that is plagued by a myriad of problems including late diagnosis often when the cancer has metastasised, no early warning symptoms and inadequate therapeutic options on diagnosis [1]. The incidence rate of pancreatic cancer for gender is close to one, with approximate rates of eight per 100,000 in men and six per 100,000 in women globally [2]. Worldwide, it is responsible for 331,000 deaths annually [2]. It is the sixth most common cause of cancer-related death in Australia and the fourth globally [3]. Despite years of research, the five year survival rate remains at approximately 5\% [1]. The median age of diagnosis has been reported to range between 66 and 68 years [4]; however, early onset pancreatic cancer occurring in patients under 
50 years of age is associated with more advanced disease at presentation and a poorer prognosis $[4,5]$. Currently $97 \%$ of the burden of disease from pancreatic cancer is due to years of life lost to premature death [6] with a median survival time of six to ten months for locally advanced disease, and three to six months for metastatic disease [7,8]. Established risk factors for pancreatic cancer include a family history of the disease and smoking, which account for $5 \%$ to $10 \%$ of cases. Other weaker associations include obesity, diabetes mellitus, chronic pancreatitis, periodontal disease, Helicobacter pylori and gallstones [4]. A challenge to the management of pancreatic cancer is the drug resistant nature of pancreatic tumour cells to gemcitabine, a pyrimidine antagonist used as the first line chemotherapeutic agent [9]. Unlike many other cancers, pancreatic cancer is characterised by several pathophysiological complications that makes it hard to treat, specifically with drugs. Traditionally, complete surgical resection provides the most recognised form of treatment [10]. A complete analysis of the difficulties in treating pancreatic cancer is aptly reviewed by Oberstein and Olive [11].

Nanoparticles are 100 to 10,000 times smaller than human cells and can interact with biological molecules intra and extracellularly [12]. Nanomedicine is the use of nanoparticles in medicine, and they can be attached to lipids or form polymers to encapsulate drugs to increase drug solubility, permeability and delivery to target cells leading to higher therapeutic efficiency [13]. Their unique properties include the ability to remain stable in the physiological environment and passively target pancreatic cancer cells via the enhanced permeability and retention effect (EPR). EPR is due to the size of the nanoparticles, which allow them to extravasate from leaky blood vessels, supplying the carcinoma and targeting it. Due to the poor lymphatic drainage in tumours, nanoparticles are able to accumulate within tumour capillaries and are large enough to escape filtration by the kidney and small enough to evade phagocytic removal by Kupffer cells and splenocytes. However, the non-physiological surface chemistry of nanoparticles may cause non-specific cellular targeting and precipitation leading to cell damage [14]. Alternatively, nanoparticles can be used to actively target tumour cells by combination of specific recognition motifs such as antibodies, sugar molecules, etc. within nanomedicine formulations [15]. Evidence suggests that active targeting by nanoparticles is efficient for poorly leaky tumours, whereas passive targeting is better for highly leaky tumours [15].

Toxicity from nanoparticles may occur as a result of composition, size or charge of the nanoparticles [16]. For example, cationic liposomal nanoparticles can interact with the extracellular matrix, serum proteins and lipoproteins, with consequent aggregation and or oxidative stress resulting in non-target tissue damage $[17,18]$. Gold nanoparticles are able to cross the placenta and damage the developing foetus [19]. Gold particles are also implicated in the induction of reactive oxygen formation and the initiation of autoimmunity [20]. Given the large diversity of materials used in the construction of nanoparticles, there is an infinite number of combinations of interactions with a high potential of negative interactions that should be taken into consideration to ensure patient safety [21].

A range of in vitro and in vivo animal studies have shown promising results using a variety of nanoparticles as nanocarriers or in combination with standard chemotherapeutic agents [22-32]. There has been a surge of interest in the use of nanoparticles as therapeutic agents for various cancers in recent years. For example, a number of clinical trials have been conducted using nanoparticles as nanocarriers for a range of solid organ tumours such as colorectal cancer [33], non-small cell lung cancer [34], gastric cancer [35], breast cancer [36] and adenocarcinomas of the oesophagus and gastroesophageal junction [37]. Therefore, the aim of this systematic review is to synthesise available literature on clinical trials performed up to March 2016 on the latest developments in the use of nanoparticles as an emerging therapy for pancreatic cancer.

\section{Methods Section}

\subsection{Literature Search}

This systematic review was performed in accordance to the Preferred Reporting Items of Systematic Reviews and Meta-Analyses (PRISMA) statement [38]. The study protocol can be 
found on the PROSPERO international prospective register of systematic review (PROSPERO 2015: CRD42015020009). Briefly, a literature search to identify studies investigating the use of nanoparticles in the management of pancreatic cancer was conducted. The Embase (1980), MEDLINE (1966), SCOPUS (1996), Web of Science (1965), and Cochrane Library databases (1992) were searched from inception to March 2016 with no language restrictions. Search terms applied included: "nanoparticles" OR "nanomedicine", [Title/Abstract] AND "pancreatic cancer management" OR "pancreatic cancer therapy", AND/OR "clinical trials" OR "clinical studies" OR "human participants". Titles and abstracts were independently screened by two authors (M.A and J.P) to identify possibly relevant studies. The full texts for articles that appear ambiguous were assessed to determine their suitability for inclusion. Database searches were supplemented by scanning the reference lists of included studies and employing the related articles function in PubMed. Subsequently, the full texts of all potentially eligible studies were evaluated in detail for inclusion by the two authors. Discrepancies were resolved in a consensus meeting between the two authors. If the two authors failed to reach a consensus, a third author (T.I.E.) was involved to make a final decision.

\subsection{Inclusion/Exclusion Criteria}

The studies included in this paper are clinical trials involving human participants diagnosed with pancreatic cancer. Interventions used in the studies must include at least one group of participants being treated with nanoparticles for pancreatic cancer, and the impact of nanoparticle treatment on the outcome of disease progression or overall survival must be measured. Studies excluded were studies not involving human participants, studies evaluating the use of nanoparticles in the imaging/diagnosis of pancreatic cancer and not the treatment, and studies evaluating the use of nanoparticles in patients without pancreatic cancer.

\subsection{Data Collection}

Two investigators (M.A and J.P) extracted data using the aforementioned strategy. Data extracted included specific details about the population, interventions, comparison, outcome (PICO) and study methods of significance to the review question and specific objectives. Authors of eligible studies were contacted where additional information was required. Data were cross-checked in a consensus meeting and again, discrepancies were resolved through discussion and mutual agreement between the two authors. The third author (T.I.E.) was available to make a final decision if required.

\subsection{Quality of Methods Assessment}

Two independent reviewers (M.A and J.P) assessed the validity of the studies using the Jadad score [39] for randomised control trials (RCT) and the Therapy CA Worksheet [40], for intervention studies. If there is any disagreement, the third reviewer (T.I.E.) interceded to make a final decision. The Jadad score assesses randomisation, blinding, and attrition to derive a score ranging from 0 (low quality) to 5 (high quality). For this review, a Jadad score greater than 2 was deemed to be of sound methodology. The Therapy CA Worksheet assesses whether the study was randomised, whether there was sufficient and complete follow up, and whether groups were analysed according to their random allocations, blinding, group characteristics and outcome (mean survival). Articles were categorised as "low", "moderate", or "high" according to analysis.

\section{Results}

\subsection{Study Selection}

We identified 210 potentially eligible studies from initial database searches after removing duplicates (Figure 1). A total of 157 articles were excluded following review of their titles and abstract. The most frequent reasons for exclusion were: not being clinical trials, not involving nanoparticles, and not involving patients with pancreatic cancer. After appraising 53 full text articles, a further 
50 were excluded because they were not clinical trials or involved the diagnosis or investigation of pancreatic cancer but not the management. Six additional studies met the inclusion criteria on hand searching the reference lists of included studies; therefore 10 studies were included in this study (Table 1). Ten clinical trials were found from the search strategy, including one randomised controlled trial and nine phase I/II clinical trials. The types of nanoparticles evaluated include nanoparticles containing a retroviral gene, gold nanoparticles, micelle nanoparticles, liposomal nanoparticles and albumin nanoparticles conjugated with chemotherapeutics [7,8,41-48]. In addition to evaluating the effects of the drug on the progression of pancreatic cancer, the maximum tolerated dose and adverse effects were also investigated.
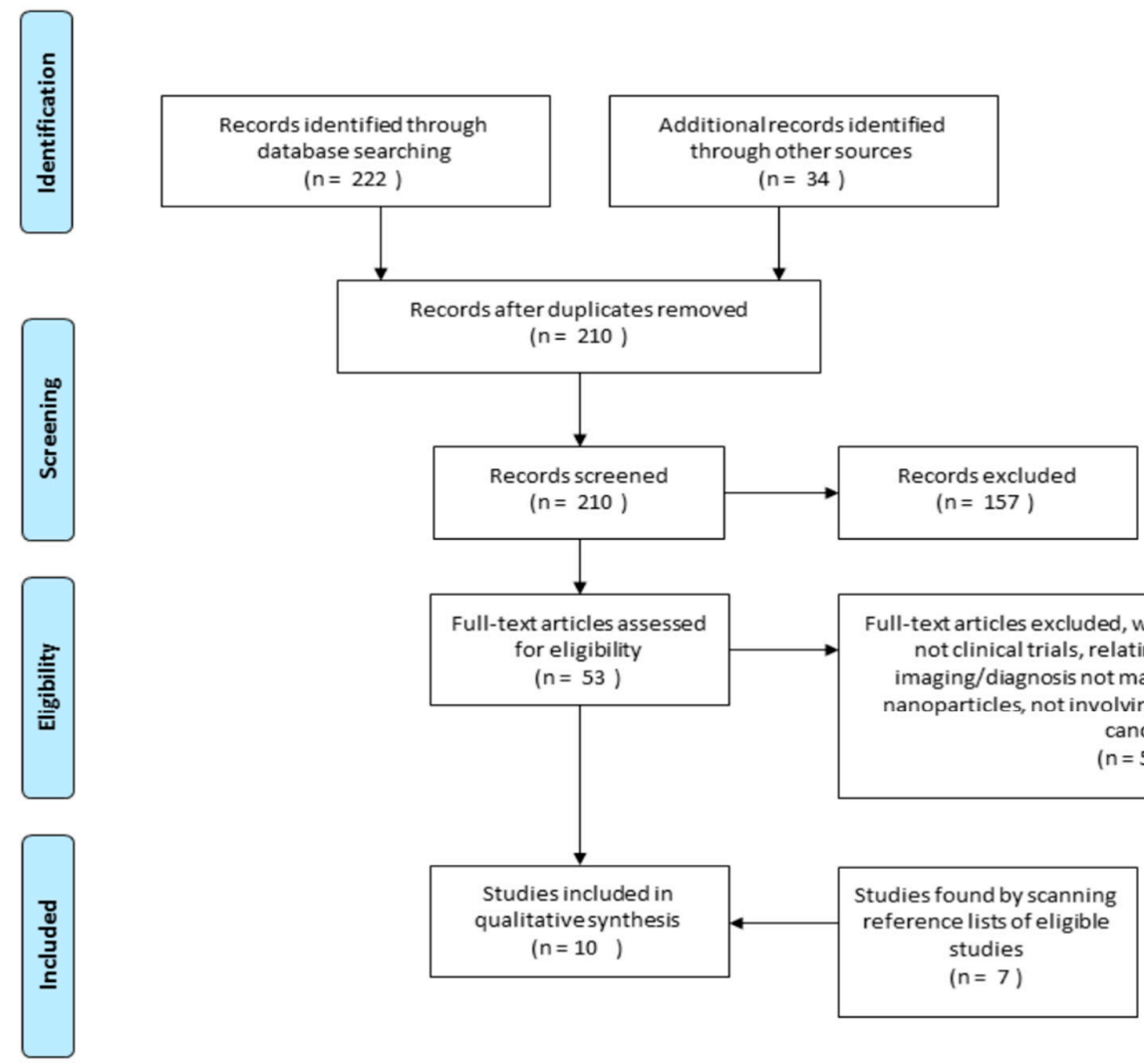

Figure 1. Flow diagram illustrating data collection protocol employed in this study.

\subsection{Study Characteristics}

All studies were prospectively performed, and conducted in hospitals, mostly in tertiary centres in the United States, Australia, Greece and Europe. Three studies (30\%) were conducted in Japan and the Philippines $[7,43,44]$. All studies stated that informed consent was obtained by the participants and were granted ethics approval. All participants had a formal diagnosis of pancreatic cancer confirmed by histology, imaging and tumour markers; the majority had metastatic disease refractory to conventional chemotherapy. The sample size of studies included ranged from 1 to 861 with a median sample size of 12 participants (interquartile range (IQR), 3-23). Participant age was not stated in the two studies, in the rest of the studies, participant age ranged from 27 to 88 years (Table 1). The median survival for participants ranged from 3.5 to 24 months, with an overall median of 8.9 months (IQR, 3.5-13.6), adverse effects ranged from minor ones such as headaches to major effect such as neutropenia and sepsis (Table 2). Two studies (20\%) did not state the median survival time, or the follow-up period $[44,46]$ (see Tables 1 and 2). For the remaining studies (80\%), the follow up period ranged from six to 48 months, with an overall median of 16 months (IQR, 9.0-33.0), (Table 2 and Figure 2). 
Table 1. Characteristics of included studies.

\begin{tabular}{|c|c|c|c|c|c|c|c|c|}
\hline Country/Region & Sample Size & $\begin{array}{l}\text { Age Range } \\
\text { (Years) }\end{array}$ & $\%$ Males & Previous Treatment & $\begin{array}{l}\text { Follow-Up } \\
\text { (Months) }\end{array}$ & Mortality (\%) & Assessment & Reference \\
\hline $\begin{array}{l}\text { North America, } \\
\text { Eastern Europe, } \\
\text { Australia, } \\
\text { Western Europe }\end{array}$ & $n=861$ & $27-88$ & 58 & None & 24 & $\begin{array}{l}\quad 692 \text { total deaths (80) } \\
333 \text { in the treatment group (77) } \\
359 \text { in the gemcitabine group (83) }\end{array}$ & $\begin{array}{l}\text { Nab-paclitaxel plus gemcitabine vs. } \\
\text { gemcitabine monotherapy }\end{array}$ & $\begin{array}{l}\text { Von Hoff et al. } \\
2013 \text { [41] }\end{array}$ \\
\hline United States & $n=19$ & $24-80$ & 47.4 & $\begin{array}{l}\text { Chemotherapy } \\
\text { (gemcitabine } \\
\text { containing regimen)* }\end{array}$ & 36 & 16 at 16 months (84) & $\begin{array}{l}\text { Determine the effectiveness of } \\
\text { nab-paclitaxel monotherapy as a } \\
\text { second line agent }\end{array}$ & $\begin{array}{l}\text { Hosein et al. } \\
2013[8]\end{array}$ \\
\hline United States & $n=67$ & $30-72$ & 48 & None & 18 & 32 at 12 months (48) & $\begin{array}{l}\text { Identify the safety and maximum } \\
\text { tolerated dose of nab-paclitaxel } \\
\text { plus gemcitabine }\end{array}$ & $\begin{array}{l}\text { Von Hoff et al. } \\
2011[42]\end{array}$ \\
\hline $\begin{array}{l}\text { United States } \\
\text { Philippines }\end{array}$ & $\begin{array}{l}\text { Trial } 1 n=6 \\
\text { Trial } 2 n=3 \\
\text { Trial } 3 n=1\end{array}$ & $\begin{array}{c}\text { Trial } 1 \\
45-64 \\
\text { Trial } 2 \\
53-68 \\
\text { Trial 3 } \\
\text { Not stated }\end{array}$ & Not stated & $\begin{array}{l}\text { Chemotherapy } \\
\text { (gemcitabine } \\
\text { containing regimen) }\end{array}$ & $\begin{array}{l}\text { Trial 1: } 13 \\
\text { Trial 2: } 6 \\
\text { Trial 3: } 6\end{array}$ & $\begin{array}{l}\text { Trial 1: } 6(100) \\
\text { Trial 2: } 1(33) \\
\text { Trial 3: } 1(100)\end{array}$ & $\begin{array}{l}\text { Trial 1: Determine the safety of } \\
\text { Rexin-G at varying doses } \\
\text { Trial 2: Determine the safety of } \\
\text { Rexin-G at varying doses } \\
\text { Trial 3: Determine the effectiveness of } \\
\text { a personal dosing regimen for Rexin-G }\end{array}$ & $\begin{array}{l}\text { Gordon et al. } \\
2006[7]\end{array}$ \\
\hline Philippines & $n=3$ & $47-56$ & 33 & $\begin{array}{l}\text { Surgical resection, } \\
\text { chemotherapy } \\
\text { (gemcitabine } \\
\text { containing regimen) } \\
\text { and external beam } \\
\text { radiotherapy }\end{array}$ & 14 & $1(33)$ & $\begin{array}{l}\text { Evaluate the safety and efficacy } \\
\text { of Rexin-G }\end{array}$ & $\begin{array}{l}\text { Gordon et al. } \\
2004[43]\end{array}$ \\
\hline United States & $n=13$ & $50-83$ & 46 & $\begin{array}{l}\text { Chemotherapy } \\
\text { (gemcitabine } \\
\text { containing regimen) }\end{array}$ & 12 & $13(87)$ & $\begin{array}{l}\text { Determine the effectiveness and most } \\
\text { appropriate dose of Rexin-G }\end{array}$ & $\begin{array}{l}\text { Chawla et al. } \\
2010[48]\end{array}$ \\
\hline Unites States & $n=12$ & $42-71$ & 75 & $\begin{array}{l}\text { Chemotherapy } \\
\text { (gemcitabine } \\
\text { containing regimen) }\end{array}$ & 6 & $11(92)$ & $\begin{array}{l}\text { Determine the effectiveness and most } \\
\text { appropriate dose of Rexin-G }\end{array}$ & $\begin{array}{l}\text { Galanis et al. } \\
2008[47]\end{array}$ \\
\hline United States & $n=3$ & Not stated & Not stated & Chemotherapy & Not analysed & Not analysed & $\begin{array}{l}\text { Evaluate the efficacy and safety } \\
\text { of CYT6091 }\end{array}$ & $\begin{array}{l}\text { Libutti et al. } \\
2010[46]\end{array}$ \\
\hline Japan & $n=11$ & $43-72$ & Not stated & Chemotherapy & Not analysed & Not analysed & $\begin{array}{l}\text { Determine the maximum tolerated } \\
\text { dose, safety and efficacy of NK105 }\end{array}$ & $\begin{array}{l}\text { Hamaguchi et al. } \\
2007 \text { [44] }\end{array}$ \\
\hline Greece & $n=24$ & $47-80$ & 46 & Chemotherapy & 8 & $17(71)$ & $\begin{array}{l}\text { Evaluate the safety and efficacy } \\
\text { of lipoplatin }\end{array}$ & $\begin{array}{l}\text { Stathopolous et al. } \\
2006 \text { [45] }\end{array}$ \\
\hline
\end{tabular}


Table 2. Summary of findings associating nanoparticles with pancreatic cancer.

\begin{tabular}{|c|c|c|c|c|c|c|c|c|}
\hline Authors & Study Design & $\begin{array}{l}\text { Nanoparticle } \\
\text { Formulation }\end{array}$ & Selection Criteria & Main Objective & Participants * & $\begin{array}{l}\text { Overall Median } \\
\text { Survival/Outcome }\end{array}$ & Adverse Reactions $†$ & Conclusion \\
\hline Von Hoff et al. [41] & $\begin{array}{l}\text { Phase III } \\
\text { Randomised } \\
\text { control trial }\end{array}$ & $\begin{array}{l}\text { Nanoparticle } \\
\text { albumin bound } \\
\text { paclitaxel } \\
\text { (nab-paclitaxel) }\end{array}$ & $\begin{array}{l}\text { Metastatic } \\
\text { pancreatic cancer } \\
\text { Karnofsky } \\
\text { performance } \\
\text { status score of } 70+\end{array}$ & $\begin{array}{l}\text { Evaluate the safety and } \\
\text { efficacy of nab-paclitaxel } \\
\text { plus gemcitabine vs. } \\
\text { gemcitabine monotherapy } \\
\text { in patients with metastatic } \\
\text { pancreatic cancer }\end{array}$ & $\begin{array}{l}n=861 . \text { Age } \\
27-88 \text { years. } \\
\text { Metastatic } \\
\text { pancreatic } \\
\text { cancer }\end{array}$ & $\begin{array}{l}8.5 \text { months } \\
(95 \% \text { CI, } 7.89 \\
\text { to } 9.53)\end{array}$ & $\begin{array}{l}\text { Major: neutropaenia } \\
\text { Minor: fatigue, } \\
\text { nausea, vomiting, } \\
\text { anorexia and } \\
\text { neuropathy }\end{array}$ & $\begin{array}{l}\text { Increased } \\
\text { overall survival. } \\
\text { Adverse effects } \\
\text { of peripheral } \\
\text { neuropathy and } \\
\text { myelosuppression } \\
\text { increased }\end{array}$ \\
\hline Hosein et al. [8] & $\begin{array}{l}\text { Phase II } \\
\text { clinical trial }\end{array}$ & $\begin{array}{l}\text { Nanoparticle } \\
\text { albumin bound } \\
\text { paclitaxel } \\
\text { (nab-paclitaxel) }\end{array}$ & $\begin{array}{l}\text { Pre-treated } \\
\text { advanced } \\
\text { pancreatic cancer }\end{array}$ & $\begin{array}{l}\text { Evaluate the safety and } \\
\text { efficacy of nab-paclitaxel } \\
\text { monotherapy in patients } \\
\text { with advanced } \\
\text { pancreatic cancer }\end{array}$ & $\begin{array}{l}n=19 . \text { Age } \\
22-80 \text { years. } \\
\text { Stage III and IV } \\
\text { pancreatic cancer }\end{array}$ & $\begin{array}{l}7.3 \text { months } \\
(95 \% \text { CI, 2.8-15.8) }\end{array}$ & $\begin{array}{l}\text { Major: sepsis } \\
\text { and neutropaenia } \\
\text { Minor: fatigue } \\
\text { and neuropathy }\end{array}$ & - \\
\hline Von Hoff et al. [42] & $\begin{array}{l}\text { Phase I/II } \\
\text { clinical trial }\end{array}$ & $\begin{array}{l}\text { Nanoparticle } \\
\text { albumin bound } \\
\text { paclitaxel } \\
\text { (nab-paclitaxel) }\end{array}$ & $\begin{array}{l}\text { Untreated } \\
\text { advanced } \\
\text { pancreatic cancer }\end{array}$ & $\begin{array}{l}\text { Identify the safety and } \\
\text { maximum tolerated dose of } \\
\text { nab-paclitaxel plus } \\
\text { gemcitabine in patients } \\
\text { with untreated advanced } \\
\text { pancreatic cancer }\end{array}$ & $\begin{array}{l}n=67 \text { Age } \\
30-72 \text { years }\end{array}$ & $\begin{array}{l}12.2 \text { months } \\
\text { (95\% CI, } 9.8 \\
\text { to } 17.9)\end{array}$ & $\begin{array}{l}\text { Major: sepsis and } \\
\text { neutropaenia } \\
\text { Minor: fatigue } \\
\text { and neuropathy }\end{array}$ & $\begin{array}{l}\text { Increased } \\
\text { overall survival. } \\
\text { Slightly higher } \\
\text { occurrence } \\
\text { of febrile } \\
\text { neutropaenia } \\
(3 \% \text { vs. } 1 \%) \\
\end{array}$ \\
\hline \multirow{3}{*}{ Gordon et al. [7] } & $\begin{array}{l}\text { (A) Phase I/II } \\
\text { clinical trial }\end{array}$ & Rexin-G & $\begin{array}{l}\text { Trial A: Locally } \\
\text { advanced } \\
\text { pancreatic cancer }\end{array}$ & $\begin{array}{l}\text { Trial A: Determine the } \\
\text { safety of Rexin-G at } \\
\text { varying doses in patients } \\
\text { with locally advanced } \\
\text { pancreatic cancer }\end{array}$ & $\begin{array}{l}\text { Trial A, } n=6 \\
\text { Age } 45-64 \text { years }\end{array}$ & $\begin{array}{l}\text { Trial A: } 24 \\
\text { months. }(95 \% \text { CI, } \\
11.1 \text { to } 39.5)\end{array}$ & $\begin{array}{l}\text { Trial A: nil minor or } \\
\text { major side effects }\end{array}$ & $\begin{array}{l}\text { Trial A: } \\
\text { Increased } \\
\text { overall survival. } \\
\text { Symptom relief }\end{array}$ \\
\hline & $\begin{array}{l}\text { (B) Phase I/II } \\
\text { clinical trial }\end{array}$ & Rexin-G & $\begin{array}{l}\text { Trial B: Metastatic } \\
\text { cancer }\end{array}$ & $\begin{array}{l}\text { Trial B: Determine the } \\
\text { safety of Rexin-G at } \\
\text { varying doses in patients } \\
\text { with various types of } \\
\text { metastatic cancer }\end{array}$ & $\begin{array}{l}\text { Trial B, } n=3 \\
\text { Age } 53-68 \text { years }\end{array}$ & $\begin{array}{l}\text { Trial B: } 9 \text { months. } \\
\text { (95\% CI, } 2.4 \\
\text { to } 14.9)\end{array}$ & $\begin{array}{l}\text { Trial B: nil minor or } \\
\text { major side effects }\end{array}$ & $\begin{array}{l}\text { Trial B: } \\
\text { Increased } \\
\text { overall survival. } \\
\text { Symptom relief }\end{array}$ \\
\hline & $\begin{array}{l}\text { (C) Expanded } \\
\text { access } \\
\text { clinical trial }\end{array}$ & Rexin-G & $\begin{array}{l}\text { Trial C: Solid } \\
\text { organ cancer }\end{array}$ & $\begin{array}{l}\text { Trial C: Determine the } \\
\text { effectiveness of a personal } \\
\text { dosing regimen for } \\
\text { Rexin-G in solid tumours. } \\
\text { Nanoparticle: Rexin-G } \\
\text { (non-replicating retroviral } \\
\text { vector expressing a } \\
\text { cytocidal gene) }\end{array}$ & $\begin{array}{l}\text { Trial C, } n=1 \\
\text { Age (not stated) }\end{array}$ & Trial C: Unknown & $\begin{array}{l}\text { Trial C: Major } \\
\text { anaemia requiring } \\
\text { red cell transfusions } \\
\text { and sporadic } \\
\text { thrombocytopaenia }\end{array}$ & $\begin{array}{l}\text { Trial C: } \\
\text { Reduction in } \\
\text { size of } \\
\text { metastatic } \\
\text { lesions }\end{array}$ \\
\hline
\end{tabular}


Table 2. Cont

\begin{tabular}{|c|c|c|c|c|c|c|c|c|}
\hline Authors & Study Design & $\begin{array}{l}\text { Nanoparticle } \\
\text { Formulation }\end{array}$ & Selection Criteria & Main Objective & Participants * & $\begin{array}{c}\text { Overall Median } \\
\text { Survival/Outcome }\end{array}$ & Adverse Reactions † & Conclusion \\
\hline Gordon et al. [43] & $\begin{array}{l}\text { Phase I/II } \\
\text { clinical trial }\end{array}$ & Rexin-G & $\begin{array}{l}\text { Stage } 4 \text { pancreatic } \\
\text { cancer }\end{array}$ & $\begin{array}{l}\text { Evaluate the safety and } \\
\text { efficacy of Rexin-G in } \\
\text { patients with stage } 4 \\
\text { pancreatic cancer. } \\
\text { Nanoparticle: Rexin-G }\end{array}$ & $\begin{array}{l}n=3 \text { Stage } 4 \\
\text { pancreatic } \\
\text { cancer }\end{array}$ & $\begin{array}{l}14 \text { months ** } \\
(95 \% \mathrm{CI},-5.8 \\
\text { to } 31.8)\end{array}$ & $\begin{array}{l}\text { Major: nil } \\
\text { Minor: nil }\end{array}$ & $\begin{array}{l}\text { Increased } \\
\text { overall survival. } \\
\text { No adverse } \\
\text { events }\end{array}$ \\
\hline Chawla et al. [48] & $\begin{array}{l}\text { Phase I/II } \\
\text { clinical trial }\end{array}$ & Rexin-G & $\begin{array}{l}\text { Gemcitabine } \\
\text { resistant } \\
\text { metastatic cancer }\end{array}$ & $\begin{array}{l}\text { Determine the effectiveness } \\
\text { and most appropriate dose } \\
\text { of Rexin-G in patients with } \\
\text { gemcitabine resistant } \\
\text { metastatic cancer. } \\
\text { Nanoparticle: Rexin G }\end{array}$ & $\begin{array}{l}n=13 \text { Age } \\
50-83 \text { years } \\
\text { Gemcitabine } \\
\text { refractory } \\
\text { Metastatic } \\
\text { disease }\end{array}$ & $\begin{array}{l}2.6 \text { months at } \\
\text { dose } 0-1, n=6 . \\
9.3 \text { months at } \\
\text { dose } 2, n=7\end{array}$ & $\begin{array}{l}\text { Major: nil } \\
\text { Minor: fatigue, chills } \\
\text { and headache }\end{array}$ & $\begin{array}{l}\text { Increased } \\
\text { overall survival. } \\
\text { Low severity of } \\
\text { adverse events }\end{array}$ \\
\hline Galanis et al. [47] & $\begin{array}{l}\text { Phase I/II } \\
\text { clinical trial }\end{array}$ & Rexin-G & $\begin{array}{l}\text { Gemcitabine } \\
\text { resistant } \\
\text { metastatic disease }\end{array}$ & $\begin{array}{l}\text { Determine the effectiveness } \\
\text { and most appropriate dose } \\
\text { of Rexin-G in patients with } \\
\text { gemcitabine resistant } \\
\text { metastatic cancer. } \\
\text { Nanoparticle: Rexin G }\end{array}$ & $\begin{array}{l}n=12 \text { Age } \\
42-71 \text { years } \\
\text { Gemcitabine } \\
\text { refractory } \\
\text { Metastatic } \\
\text { disease }\end{array}$ & $\begin{array}{l}3.5 \text { months from } \\
\text { treatment } \\
\text { initiation }\end{array}$ & $\begin{array}{l}\text { Major: nil } \\
\text { Minor: nausea, fever, } \\
\text { diarrhoea, } \\
\text { hypermagnesaemia } \\
\text { and raised liver } \\
\text { enzymes (alanine } \\
\text { aminotransferase } \\
\text { (ALT), aspartate } \\
\text { aminotransferase } \\
\text { (AST), alkaline } \\
\text { phosphate (ALP)) }\end{array}$ & $\begin{array}{l}\text { Significant } \\
\text { increase in } \\
\text { tumour size. } \\
\text { Low severity of } \\
\text { adverse events }\end{array}$ \\
\hline Libutti et al. [46] & $\begin{array}{l}\text { Phase I } \\
\text { clinical trial }\end{array}$ & $\begin{array}{l}\text { Colloid gold } \\
\text { nanoparticle } \\
\text { PEGlycated } \\
\text { with } \\
\text { recombinant } \\
\text { TNF }\end{array}$ & Solid organ cancer & $\begin{array}{l}\text { Evaluate the efficacy and } \\
\text { safety of CYT6091 in } \\
\text { patients with advanced } \\
\text { stage cancer }\end{array}$ & $\begin{array}{l}n=3 \text { with } \\
\text { Pancreatic } \\
\text { cancer }\end{array}$ & Not specified & $\begin{array}{l}\text { Major: nil } \\
\text { Minor: lymphopenia, } \\
\text { hypoalbuminaemia, } \\
\text { hypokalaemia, } \\
\text { hypophosphataemia } \\
\text { and deranged liver } \\
\text { function tests } \\
\text { (bilirubin and AST) }\end{array}$ & $\begin{array}{l}\text { Nanoparticle } \\
\text { CYT6091 } \\
\text { preferentially } \\
\text { targets tumour } \\
\text { tissue }\end{array}$ \\
\hline
\end{tabular}


Table 2. Cont

\begin{tabular}{|c|c|c|c|c|c|c|c|c|}
\hline Authors & Study Design & $\begin{array}{l}\text { Nanoparticle } \\
\text { Formulation }\end{array}$ & $\begin{array}{c}\text { Selection } \\
\text { Criteria }\end{array}$ & Main Objective & Participants * & $\begin{array}{c}\text { Overall Median } \\
\text { Survival/Outcome }\end{array}$ & Adverse Reactions † & Conclusion \\
\hline $\begin{array}{l}\text { Hamaguchi } \\
\text { et al. [44] }\end{array}$ & $\begin{array}{l}\text { Phase I } \\
\text { clinical trial }\end{array}$ & $\begin{array}{l}\text { NK105 (micelle } \\
\text { nanoparticle) }\end{array}$ & $\begin{array}{l}\text { Refractory solid } \\
\text { organ cancers }\end{array}$ & $\begin{array}{l}\text { Determine the maximum } \\
\text { tolerated dose, safety and } \\
\text { efficacy of NK105 in } \\
19 \text { patients with refractory } \\
\text { solid organ cancers }\end{array}$ & $\begin{array}{l}n=11 \text { Age } \\
43-72 \text { years } \\
\text { (range for all } \\
\text { participants) }\end{array}$ & $\begin{array}{l}\text { Not specified. } \\
\text { Antitumour } \\
\text { response of } 1 \text { year } \\
\text { for } 1 \text { patient, one } \\
\text { had stable disease } \\
\text { for } 4 \text { weeks }\end{array}$ & $\begin{array}{l}\text { Major: neutropaenia } \\
\text { Minor: fever. Nausea, } \\
\text { fatigue, stomatitis, } \\
\text { rash, alopecia (for all } \\
\text { participants with a } \\
\text { solid organ cancer) }\end{array}$ & $\begin{array}{l}\text { Decrease in size } \\
\text { of metastatic } \\
\text { lesions. Low } \\
\text { severity of } \\
\text { adverse events }\end{array}$ \\
\hline $\begin{array}{l}\text { Stathopolous } \\
\text { et al. [45] }\end{array}$ & $\begin{array}{l}\text { Phase I/II } \\
\text { clinical trial }\end{array}$ & Lipoplatin & $\begin{array}{l}\text { Refractory } \\
\text { pancreatic cancer }\end{array}$ & $\begin{array}{l}\text { Evaluate the safety and } \\
\text { efficacy of lipoplatin and } \\
\text { gemcitabine in patients } \\
\text { with refractory } \\
\text { pancreatic cancer }\end{array}$ & $\begin{array}{l}n=24 \text { Age } \\
47-80 \text { years. } \\
\text { Refractory } \\
\text { pancreatic } \\
\text { cancer }\end{array}$ & $\begin{array}{l}4 \text { months from } \\
\text { beginning of } \\
\text { treatment. (Range } \\
2-8 \text { months) }\end{array}$ & $\begin{array}{l}\text { Major: no } \\
\text { neurological/renal } \\
\text { toxicity } \\
\text { Minor: self- resolving } \\
\text { abdominal pain. } \\
\text { Myelotoxicity } \\
\text { (grade 3) }\end{array}$ & $\begin{array}{l}\text { Treatment } \\
\text { resulted in } \\
\text { symptom relief } \\
\text { and a partial } \\
\text { response/stable } \\
\text { disease. Low } \\
\text { severity of } \\
\text { adverse events }\end{array}$ \\
\hline
\end{tabular}

${ }^{*}=$ only includes participants with pancreatic cancer. ${ }^{* *}=$ including 1 patientt still alive after 20 months. † Major reactions include clinically significant neurotoxicity, haemotoxicity

and renal/liver toxicity. Minor reactions include non-life threatening symptoms that resolve with minimal or no intervention. 


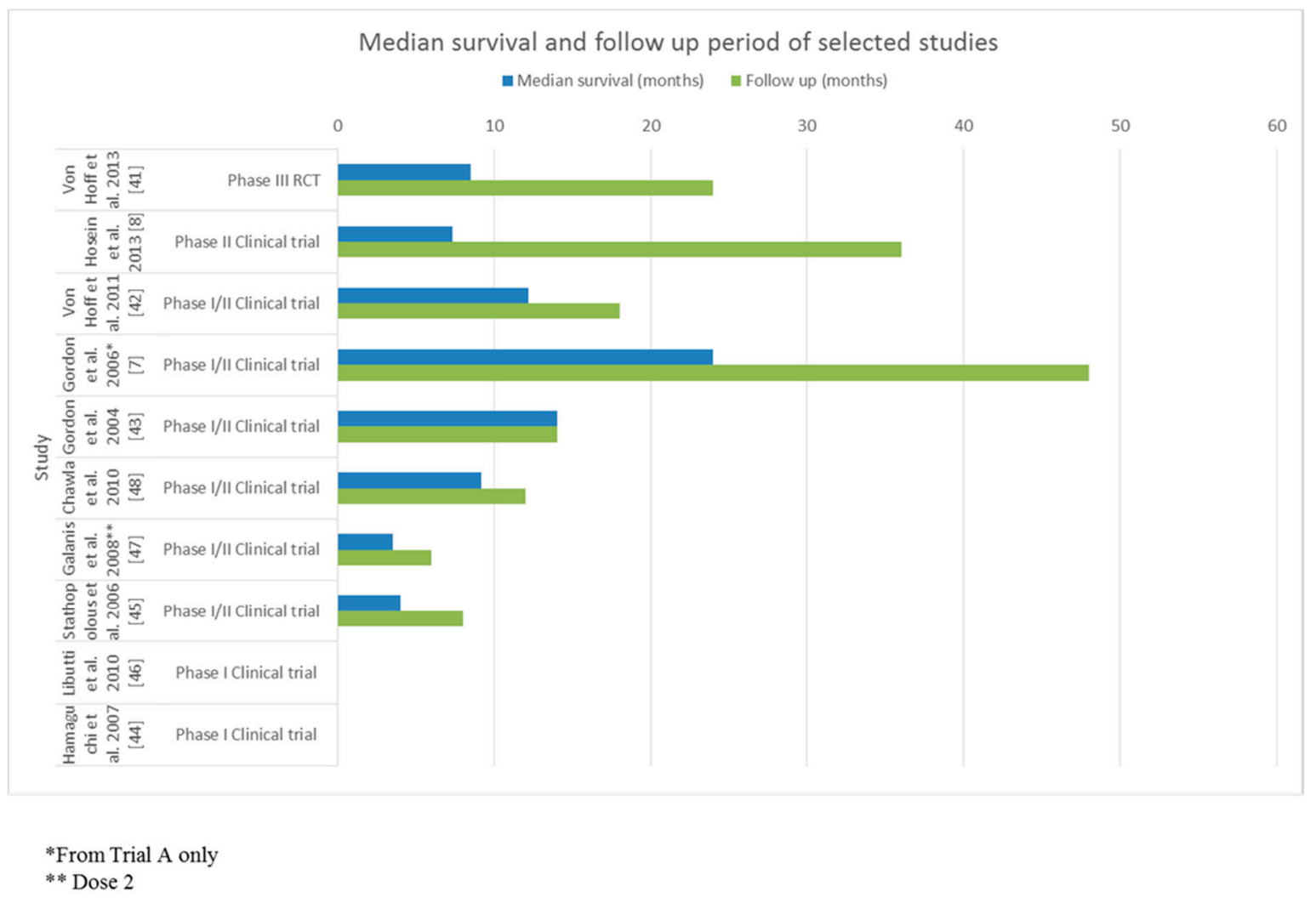

Figure 2. Median survivals and follow up period of selected studies. Abbreviations; RCT = randomised controlled clinical trial.

\section{Synthesis of Study Results}

\subsection{Nanoparticle Albumin Bound Paclitaxel}

Paclitaxel is a plant chemotherapeutic alkaloid that is mixed with human serum albumin in an aqueous solvent and is under high pressure to form a 100-200 nm drug nanoparticle albumin bound paclitaxel (nab-paclitaxel) [49]. One phase I/II study and one phase II study were found on investigating the effect of nab-paclitaxel $[8,42]$. Promising beneficial effects of a combination of nab-paclitaxel and gemcitabine were reported in the first study [42]. The second study involved patients with advanced pancreatic cancers, and failed to show convincing therapeutic effect of this medication [8]. In a phase I/II study involving 67 patients randomised into three groups, 20 receiving $100 \mathrm{mg} / \mathrm{m}^{2}, 44$ receiving $125 \mathrm{mg} / \mathrm{m}^{2}$ and three receiving $150 \mathrm{mg} / \mathrm{m}^{2}$ of nab-paclitaxel, followed by $1000 \mathrm{mg}$ of gemcitabine on three days in every 28 day cycle. Von Hoff and colleagues reported that the maximum tolerated dose of nab-paclitaxel was $125 \mathrm{mg} / \mathrm{m}^{2}$ once a week for three weeks plus $1000 \mathrm{mg} / \mathrm{m}^{2}$ gemcitabine every 28 days [42]. They found that the dose limiting adverse reactions were neutropaenia and sepsis, the progression free survival was 7.9 months (95\% CI 5.8-11 months) with a median overall survival of 12.2 months (95\% CI 9.8-17.9 months) and a one-year survival rate of $48 \%$. Positron emission tomography (PET) analysis of patients showed a median decrease in metabolic activity of $79 \%$ in all three treatment groups with a higher reduction in metabolic activity in the group receiving $125 \mathrm{mg} / \mathrm{m}^{2}$ nab-paclitaxel-gemcitabine compared to those receiving $100 \mathrm{mg} / \mathrm{m}^{2}$, $68 \%$ vs. $53 \%$, respectively ( $p=0.044)$. However, in 19 patients with stage III/IV pancreatic cancer who progressed on gemcitabine-based treatment, and recruited into a single-arm, open-label phase II clinical trial of nab-paclitaxel, Hosein and colleague reported similar side effects to the Van Hoff study above, a progression free survival of 1.7 months (95\% CI, 1.5-3.5 months), good overall tolerance, and median overall survival of 7.3 months (95\% CI, 2.8-15.8 months) [8]. 
In a more recent phase III RCT involving 861 participants with metastatic pancreatic cancer randomly assigned to a treatment regimen involving nab-paclitaxel and gemcitabine or gemcitabine alone, the same authors reported a significant increase in median overall survival in the group receiving nab-paclitaxel compared to the group receiving gemcitabine alone of 8.5 months and 6.7 months, respectively $(p<0.001)$ [41]. At the one-year mark, the survival was 5.5 months in the nab-paclitaxel-gemcitabine group compared to 3.7 months in the gemcitabine group $(p<0.001)$. The adverse events associated with treatment were more prominent in patients receiving nab-paclitaxel plus gemcitabine; these include: neutropaenia (38\% in the nab-paclitaxel plus gemcitabine group, $27 \%$ in the gemcitabine group), fatigue (17\% in the nab-paclitaxel plus gemcitabine group, $7 \%$ in the gemcitabine group) or neuropathy (17\% in the nab-paclitaxel plus gemcitabine group, $1 \%$ in the gemcitabine group). However, the rates of myelosuppression and neuropathy were also increased [41]. Taken together, these studies suggest that nab-paclitaxel may serve as a promising treatment modality in the future.

\subsection{Pathotrophic Nanoparticle Gene Delivery}

Rexin-G is a pathotropic retroviral based nanoparticle/gene delivery vector produced by transient co-transfection of human embryonic kidney 293T cells with the Moloney murine leukaemia virus, and encodes a dominant negative mutant construct of the human cyclin G1 gene [43]. The first clinical trial using Rexin-G in the treatment of pancreatic cancer in the Philippines was performed by Gordon et al. [43]. They reported tumour stabilisation in doses ranging from $2.7 \times 10^{10}$ to $3 \times 10^{11}$ colony forming units; tumour growth was arrested in three of three patients with no experience of dose limiting toxicity. Two patients were stable five and 14 months from diagnosis, respectively. There were no adverse events such as bone marrow suppression, significant alterations in liver and kidney function, nausea or vomiting, mucositis or hair loss. In a further multicentre/country study, the same performed a series of clinical trials investigating the use of Rexin-G in patients with locally advanced or metastatic pancreatic cancer [7]. Clinical trial A assessed the use of Rexin-G in six patients with pancreatic cancer. Five patients showed a partial response and one had stable disease. Half of the participants had a $>30 \%$ reduction in tumour size by Response Evaluation Criteria in Solid Tumours (RECIST) or by tumour volume measurement. Progression-free survival ranged between two to nine months with a mean of 3.8 months. The median overall survival of patients treated with Rexin-G from diagnosis was 24 months, whereas that for patients on conventional therapy was 4.4 months. Clinically, all six participants had no associated nausea, vomiting, diarrhoea; mucositis, hair loss or neuropathy, although three participants had symptomatic relief of pain. The only adverse reactions association with treatment were a generalised rash and urticaria in two participants [7].

Clinical trial B investigated the effectiveness of Rexin-G in patients with metastatic cancer, and this involved three patients with metastatic pancreatic cancer. For the patients with metastatic pancreatic cancer, two had a partial response with a $>30 \%$ reduction in tumour size, necrosis of the primary tumour and decrease in number and size of metastatic nodules. One patient had progressive disease. All three had symptomatic relief of pain. These patients did not suffer from any treatment related adverse reactions [7].

Clinical trial $C$ investigated the effectiveness of using a personalised dosing regimen (Calculus of Parity) to calculate the dose of Rexin-G in patients with metastatic cancer. This trial involved two patients with metastatic pancreatic cancer. Both patients responded to therapy with one demonstrating necrosis and cystic conversion of an unresectable pancreatic tumour, whilst the other patient showed significant reduction in the primary pancreatic tumour and a reduction from 28 to 12 pulmonary nodules. None of the patients experienced nausea, vomiting, diarrhoea, mucositis, hair loss or neuropathy. However, two patients developed anaemia requiring packed red cell transfusions, which was potentially due to bleeding into the necrotic tumours [7].

In a similar study involving 13 patients with metastatic pancreatic cancer resistant to standard chemotherapy containing gemcitabine, Chawla et al. reported that four patients left the trial due to 
complications related to their disease or personal reasons after less than one cycle of therapy [48]. They found that the median overall survival was 2.6 months for six patients at dose level $0-1$ $\left(1 \times 10^{11}\right.$ colony forming units, $2-3$ times a week) and 9.3 months for seven patients at dose level 2 $\left(2 \times 10^{11}\right.$ colony forming units, thrice a week for four weeks). Treatment related grade 1 adverse events were experienced by three participants; two experienced fatigue and one experienced chills with a headache [48].

Galanis et al. [47] carried out a study to determine the dose of Rexin-G that provided the best response in 12 patients with gemcitabine refractory metastatic pancreatic cancer. The investigators found that at a dose level between $1 \times 10^{11}$ to $6 \times 10^{11}$ colony forming units per cycle, the treatment was mostly well tolerated with only one participant experiencing a dose limiting toxicity of raised serum transaminases at a dose of $1.5 \times 10^{11}$ colony forming units. The median survival was 3.5 months with 11 participants showing progressive disease and one showing radiographically stable disease with clinical deterioration. Although the treatment was well tolerated, there was no evidence of clinical anti-tumour activity; CT and PET scans pre-treatment at day 28 showed significantly increased tumour volume with a mean increase of $204.5 \%(p=0.001)$, increase in CA 19.9 by a mean of $204.5 \%(p=0.001)$, median increase in PET standardized uptake of fluorodeoxyglucose (FDG) was 36.3\% ( $p=0.0244)$.

Overall, Rexin-G is reported to selectively targets metastatic cancer sites with associated angiogenesis and increase mean survival in patients with pancreatic cancer.

\subsection{Gold Nanoparticles}

Libutti et al. conducted a clinical trial using CYT-6091 in 30 patients with advanced solid organ cancer, including three participants with pancreatic cancer [46]. CYT-6091 consists of colloid gold nanoparticles with surface bound recombinant tumour necrosis factor and thiolyated polyethylene glycol. They found that CYT9061 selectively targeted tumour tissue in the three patients with pancreatic adenocarcinoma. Electron microscopy examination of biopsies of tumour and adjacent healthy tissue showed that particles in normal tissues were between 0-2 in the three participants with pancreatic adenocarcinoma and 5-6 particles in tumour tissue. There were minor adverse effects reported including lymphopenia, hypoalbuminaemia, electrolyte disturbances and derangement in hepatic enzymes, but did not specify any overall survival [46]. This study suggests that colloid gold nanoparticles combined with recombinant tumour necrosis factor selectively target pancreatic cancer sites, aiding the delivery of chemotherapeutic agents to pancreatic cancer tissue.

\subsection{Micelle Nanoparticles}

Micelle nanoparticles are constructed by using polyethylene glycol as the hydrophilic component and modified polyaspartate as the hydrophobic component which entraps the drug paclitaxel [44]. Paclitaxel is an antimicrotubule chemotherapeutic agent for a range of solid organ cancers; however, its efficacy is limited by poor water solubility [44]. The use of a micelle nanoparticle formulation overcomes this by encapsulating paclitaxel in a "core-shell" that is water soluble and has been shown to have enhanced anti-tumour activity due to the EPR effect $[44,50]$.

Hamaguchi et al. performed a phase I clinical trial to determine the maximum tolerated dose, dose related toxicities, and pharmacokinetics of NK105, a micelle carrier system for paclitaxel [44]. Nineteen cancer patients were recruited, including 11 patients with pancreatic cancer who received IV infusion of NK105. NK105 was generally well tolerated, six patients developed peripheral neuropathy, none of the patients developed clinically significant haematological toxicities. A partial response was seen in a patient with metastatic pancreatic cancer who received $150 \mathrm{mg} / \mathrm{m}^{2}$, their liver metastases reduced in size by $90 \%$, although the effect on pancreatic cancer was not specifically reported. Hence, it is unclear whether micelle nanoparticles would be useful in pancreatic cancer management. 


\subsection{Liposomal Nanoparticles}

A liposomal-cisplatin nanoparticle (lipoplatin) is constructed from cisplatin and liposomes composed of dipalmitoyl phosphatidyl glycerol, methoxy-polyethylene glycol-distearoyl phosphatidylethanolamine, and soy phosphatidyl choline [51]. Stathopoulos et al. investigated the efficacy and safe dose of lipoplatin with gemcitabine in 24 patients with refractory pancreatic cancer [45]. Response to treatment was determined by CT (computed tomography) measurement of the tumours. A partial response ( $>50 \%$ reduction in the sum of products of the perpendicular diameters of lesions lasting for at least four weeks) was seen in two patients. Stable disease $(<50 \%$ reduction and $<25 \%$ increase in the size of the products of two perpendicular diameters of lesions for at least eight weeks) was seen in 14 patients who had. Median survival from the beginning of treatment was four months. The treatment dose of fortnightly administration of up to $100 \mathrm{mg} / \mathrm{m}^{2}$ of lipoplatin and $1000 \mathrm{mg} / \mathrm{m}^{2}$ of gemcitabine was well tolerated by the participants with no evidence of neurotoxicity or renal toxicity.

\subsection{Quality of Methods of Included Studies}

The quality of methods assessment of 10 studies included is outlined in Table 3. With a Jadad score of 3, the one RCT included is of reasonably sound methodology, (Table 3a). In the other nine non-randomised clinical trials included, the Therapy CA Worksheet indicates that included studies ranged from low to moderate quality of methodology (Table 3b). Common weaknesses identified were: failure to blind, small sample sizes and/ or failure to justify sample size, and failure to identify and account for all confounders. 
Table 3. Quality assessment of included studies.

\begin{tabular}{|c|c|c|c|c|c|c|c|c|}
\hline \multirow{2}{*}{$\begin{array}{c}\text { Author and Year } \\
\text { Von Hoff et al. } \\
2013 \text { [41] }\end{array}$} & \multirow{2}{*}{$\begin{array}{c}\text { Randomisation } \\
2\end{array}$} & \multicolumn{3}{|c|}{ Blinding } & \multicolumn{2}{|c|}{ An Account of All Patients } & \multicolumn{2}{|l|}{ Total Score } \\
\hline & & & 0 & & 1 & & 3 & \\
\hline \multicolumn{9}{|c|}{ Table 3b. Quality assessment of included studies using the Therapy CA Worksheet. } \\
\hline Author and Year & Randomisation & $\begin{array}{c}\text { Sufficient and } \\
\text { Complete Follow-Up }\end{array}$ & $\begin{array}{c}\text { Groups } \\
\text { Analysed } \\
\text { as per } \\
\text { Randomisation }\end{array}$ & Blinding & $\begin{array}{l}\text { Groups Treated } \\
\text { Equally Apart } \\
\text { from } \\
\text { Intervention }\end{array}$ & $\begin{array}{c}\text { Groups Have Similar } \\
\text { Characteristics at the } \\
\text { Start }\end{array}$ & $\begin{array}{l}\text { Median } \\
\text { Survival } \\
\text { (Months) }\end{array}$ & $95 \% \mathrm{CI}$ \\
\hline Hosein et al. 2013 [8] & $\mathrm{N}$ & Y & $\mathrm{N} / \mathrm{A}$ & $\mathrm{N}$ & $\mathrm{N} / \mathrm{A}$ & $\mathrm{N} / \mathrm{A}$ & 7.3 & $2.8-15.8$ \\
\hline Von Hoff et al. 2011 [42] & $\mathrm{N}$ & Y & $\mathrm{N} / \mathrm{A}$ & $\mathrm{N}$ & $\mathrm{N} / \mathrm{A}$ & $\mathrm{N} / \mathrm{A}$ & 12.2 & $9.8-17.9$ \\
\hline \multirow{3}{*}{ Gordon et al. 2006 [7] } & Trial A: N & Trial A: Y & Trial A: N/A & Trial A: N & Trial A: N/A & Trial A: N/A & Trial A: 25 & $12.36-38.30 *$ \\
\hline & Trial B: N & Trial B:Y & Trial B: N/A & Trial B: N & Trial B: N/A & Trial B: N/A & Trial B: 9 & $3.58-13.76^{*}$ \\
\hline & Trial C: N & Trial C: N & Trial C: N/A & Trial C: N & Trial C: N/A & Trial C: N/A & Trial C: N/A & N/A \\
\hline Gordon et al. 2004 [43] & $\mathrm{N}$ & Y & $\mathrm{N} / \mathrm{A}$ & $\mathrm{N}$ & N/A & $\mathrm{N} / \mathrm{A}$ & 13 & $-2.30-28.30 *$ \\
\hline Chawla et al. 2010 [48] & $\mathrm{N}$ & Y & $\mathrm{N} / \mathrm{A}$ & $\mathrm{N}$ & $\mathrm{N} / \mathrm{A}$ & $\mathrm{N} / \mathrm{A}$ & $\begin{array}{c}\text { Dose } 0-1: 4.3 \\
\text { Dose 2:9.2 }\end{array}$ & $\mathrm{N} / \mathrm{A}+$ \\
\hline Galanis et al. 2008 [47] & $\mathrm{N}$ & $\mathrm{Y}$ & $\mathrm{N} / \mathrm{A}$ & $\mathrm{N}$ & $\mathrm{N} / \mathrm{A}$ & $\mathrm{N} / \mathrm{A}$ & 3.5 & $2.66-4.34 *$ \\
\hline Libutti et al. 2010 [46] & $\mathrm{N}$ & $\mathrm{N}$ & $\mathrm{N} / \mathrm{A}$ & $\mathrm{N}$ & $\mathrm{N} / \mathrm{A}$ & N/A & N/A & $\mathrm{N} / \mathrm{A}+$ \\
\hline Hamaguchi et al. 2007 [44] & $\mathrm{N}$ & $\mathrm{N}$ & $\mathrm{N} / \mathrm{A}$ & $\mathrm{N}$ & $\mathrm{N} / \mathrm{A}$ & $\mathrm{N} / \mathrm{A}$ & $\mathrm{N} / \mathrm{A}$ & $\mathrm{N} / \mathrm{A}+$ \\
\hline Stathopolous et al. 2006 [45] & $\mathrm{N}$ & $\mathrm{Y}$ & $\mathrm{N} / \mathrm{A}$ & $\mathrm{N}$ & $\mathrm{N} / \mathrm{A}$ & $\mathrm{N} / \mathrm{A}$ & 4 & $3.37-4.63 *$ \\
\hline
\end{tabular}

Abbreviations: $\mathrm{CI}=$ Confidence interval; $\mathrm{Y}=$ Yes; $\mathrm{N}=\mathrm{No} ; \mathrm{N} / \mathrm{A}=$ Not applicable. ${ }^{*}$ Calculated based on values in paper. + Unable to calculate based on information in paper 


\section{Discussion}

Pancreatic cancer remain a devastating cause of death globally [3], and is plagued by limited therapeutic options on diagnosis [1]. A significant challenge in the management of pancreatic cancer is the drug resistant nature of first line chemotherapy [9]. The ability of nanoparticles to bypass some of these difficulties due to their unique characteristics has enabled their trials as putative therapeutic agents for pancreatic cancers in recent years. This article appraised available literature on clinical trials performed up to March 2015 on the use of nanoparticles as therapeutic agents for pancreatic cancer.

Overall, clinical trials have demonstrated that nanoparticles can improve the efficacy of anticancer agents [7,8,41-48]. For example, nanoparticles were shown to increase the delivery, cellular targeting of gemcitabine the current first line chemotherapy for pancreatic cancer, whilst reducing associated adverse effects [14]. Gemcitabine is known to be plagued by issues such as low solubility and poor expression of intracellular gemcitabine-uptake regulating nucleoside transporters on pancreatic cells [27]. Additionally, multidrug resistance proteins, the anti-tumour microenvironment such as epithelial-mesenchymal transition cells with migratory and invasive properties, and the hypoxic stroma in pancreatic cancers also play a role as a physical barrier preventing chemotherapeutic agents from targeting pancreatic cancer cells [4]. The evidence reviewed in this article suggest that these barriers are broken by nab-paclitaxel which increases drug bioavailability and delivery to the malignant tissue [31,48,49]. Nab-paclitaxel, for example, has been reported to not only enhance the effect of paclitaxel by increasing its activity and reducing toxicity, but to also acts synergistically with gemcitabine [42]. Since the development of gemcitabine in 1996, eight phase III clinical trials involving chemotherapeutic [52-57] or biologic agents [58-60] have failed to show an improvement in survival. Improvement was seen in 2006 when a phase III randomised controlled trial demonstrated that erlotinib and gemcitabine lead to an overall survival of 6.42 months which was significantly prolonged compared to gemcitabine and a placebo [61].

Rexin-G was the first targeted genetic medicine reported to show an increase in overall survival with no organ related toxicity [48]. None of the studies reviewed reported any systematic toxicity $[7,47,48]$. Although one study failed to show any evidence of vector specific- or neutralising antibodies in the sera of the participants, and no evidence of vector DNA integration or recombination events in non-target organs including lymphocytes [48]. Collectively, these studies suggest that Rexin-G is superior to standard chemotherapy in terms of safety profile, efficacy in the management of gemcitabine resistant pancreatic cancer, as well as improving quality of life.

Libutti et al. performed the first clinical trial involving CTY-6091 and reported potential tumour reducing effects with a moderate safety profile [46]. This outcome is supported by previously reported data on the safety of colloid gold in medicine such as in the treatment for rheumatoid arthritis [62]. In support, pre-clinical studies employing CYT-6091 suggest increased accumulation in solid tumours and a reduction in systemic toxicity [63]. Similarly studies using liposomal nanoparticles was reported to exhibit a high safety profile, low toxicity, adequate tumour targeting ability, low immunogenicity and no renal or neurological toxicity [45].

\subsection{Current Progress}

As demonstrated in this systematic review, there is indeed ongoing research into the development of nanotechnology based on the unique tumour microenvironment, which are able to deliver clinically pertinent doses of active formulations to the tumour site while evading various physiological barriers in the fight against pancreatic cancers. Evidence suggests that there is progress in developing nanoparticles able to increase the efficacy per dose of a therapeutic agent by increasing its bioavailability, and that can also be modified for targeted specificity toward cancer cells with negligible damage to non-target tissues which is generally associated with current chemotherapy [7,41,43-48,64-67]. With the establishment of the Alliance for Nanotechnology in Cancer responsible for fostering innovation and collaboration among researchers to expedite the use of nanotechnology for cancer diagnosis and therapy by the United States National Cancer Institute in September 2004. There have 
been some success in the design and synthesis of nanoparticles that can encapsulate and deliver a diverse suite of cancer targeting therapeutic formulations such as nanoparticles delivering chemotherapy drugs or RNA interference inhibitors [68-71], and nanoparticles co-delivering two chemotherapeutic drugs at a fraction of the dose with minimal side effects and with the potential to reduce cost $[64,65]$. There are many other emerging strategies such as the use of nanoparticles (e.g., magnetic nanoparticles) synergistically to improve photodynamic therapy (use of specific wavelength irradiation to selectively kill cancer cells via oxidative stress and caspase-dependent apoptotic mediated mechanisms) [72,73], and photothermal therapy (use of near-infrared light of longer wavelengths to ablate cancer cells) [74], or both [75], or by employing nanoparticles composed of high atomic numbers such as gold nanoparticles [76], titanium oxide nanotubes [77], or gadolinium-based nanoparticles [78] to enhance radiation therapy.

\subsection{Limitations}

When nanoparticles enter the biological environment, the surface proteins associated with the nanoparticle interact with biological molecules; this interaction depends highly on the composition of proteins on the nanoparticle. Inappropriate surface chemistry of nanoparticles have the potential to cause unwanted reactions, reduction in efficacy and adverse effects [21].

Clinical trials in this study involve participants who have refractory pancreatic cancer; further studies need to be done to ascertain the effects of nanoparticles on patients with less localised pancreatic cancer.

Studies included in this review were heterogeneous precluding a meta-analysis. Variability was identified in the way the dosage of nanoparticles for administration was determined; since dosage is related to toxicity, this may be a confounder in the frequency and severity of side effects found. In order for the studies to be comparable, a standardised form of dosing should be used in future studies.

Nanoparticles can be generated in many forms, and only a few of them have been investigated in clinical trials as demonstrated by this study. Many other nanoparticle types have been investigated in in vivo studies with promising results $[64,65]$. In the future, it is expected that many more clinical trials will be published on these emerging therapies such as quantum dots, carbon nanotubes, paramagnetic nanoparticles, metallic nanoparticles and silver nanoparticles. Since great diversity exists in the form that nanoparticles can take, this study is only representative of gold nanoparticles, micelle nanoparticles, Rexin-G and liposomal nanoparticles. The nanoparticles used in the clinical trials identified in this study vary greatly among themselves, and the results cannot be generalised to all the forms of nanoparticles available.

Multiple cell lines of origin for pancreatic cancer exist; the trials included in this did not identify the cell line of pancreatic cancer for the participants. This is a limitation, as the types of mutation present in the cell line provides information on the growth characteristics, tumourigenicity and chemosensitivity of the tumour [79]. For example, panc- 1 cells have a $5 \times$ greater ability to invade compared to BxPC-3 cells and Capan-1 cells have a higher angiogenic potential compared to Panc-1 cells [80-83]. Although there is limited evidence on the best method to obtain cell line information, further research in this area can enhance the interpretation of results from the use of nanomedicine.

\subsection{Future Research}

These studies highlight the potential of nanoparticles to be used in human participants; the results demonstrate a safe toxicity profile and ability to increase overall survival. Despite promising research showing the efficacy and safety of nanoparticles in in vitro and in vivo studies in animal models, more research is required to determine the clearance mechanisms of nanoparticles and their molecular interactions in human participants [14]. The long-term side effects of using nanoparticles are yet to be defined. More randomised controlled trials are required to determine implications of nanomedicine on the quality of life of patients with pancreatic cancer. 


\section{Conclusions}

Clinical trials have been performed involving a retroviral vector, albumin, colloid gold, micelles and liposomes. The clinical trials have demonstrated that nanoparticles can be used in conjunction with chemotherapeutic and other agents increasing their efficacy whilst reducing their toxicity. Increased efficacy of treatment with nanoparticles may improve the clinical outcomes and quality of life in patients with pancreatic cancer, although the long-term side effects of these agents remain unknown.

Acknowledgments: Special thanks to the Research Team, Public Health and Tropical Medicine, James Cook University for technical guidance.

Author Contributions: Minnie Au and Theophilus I. Emeto designed and wrote the article. Minnie Au, Jacinta Power and Theophilus I. Emeto critically appraised the literature. Venkat N. Vangaveti and Hock C. Lai reviewed and edited the article. All authors read and approved the final manuscript for submission.

Conflicts of Interest: The authors declare no conflict of interest.

\section{Abbreviations}

The following abbreviations are used in this manuscript:

$\begin{array}{ll}\% & \text { percentage } \\ \text { CI } & \text { confidence interval } \\ \text { FDG } & \text { fluorodeoxyglucose } \\ \mathrm{IV} & \text { intravenous } \\ \mathrm{mg} / \mathrm{m}^{2} & \text { milligram per meter square } \\ \mathrm{nab}-\mathrm{paclitaxel} & \text { nanoparticle albumin bound-paclitaxel } \\ \mathrm{RCT} & \text { randomised control trials } \\ \mathrm{PET} & \text { positron emission tomography }\end{array}$

\section{References}

1. Robotin, M.C.; Jones, S.C.; Biankin, A.V.; Waters, L.; Iverson, D.; Gooden, H.; Barraclough, B.; Penman, A.G. Defining research priorities for pancreatic cancer in Australia: Results of a consensus development process. Cancer Causes Control 2010, 21, 729-736. [CrossRef] [PubMed]

2. Ferlay, J.; Soerjomataram, I.; Dikshit, R.; Eser, S.; Mathers, C.; Rebelo, M.; Parkin, D.M.; Forman, D.; Bray, F. Cancer incidence and mortality worldwide: Sources, methods and major patterns in globocan 2012. Int. J. Cancer 2015, 136, E359-E386. [CrossRef] [PubMed]

3. Hariharan, D.; Saied, A.; Kocher, H. Analysis of mortality rates for pancreatic cancer across the world. $H P B$ 2008, 10, 58-62. [CrossRef] [PubMed]

4. Ansari, D.; Chen, B.-C.; Dong, L.; Zhou, M.-T.; Andersson, R. Pancreatic cancer: Translational research aspects and clinical implications. World J. Gastroenterol. 2012, 18, 1417-1424. [CrossRef] [PubMed]

5. Tingstedt, B.; Weitkamper, C.; Andersson, R. Early onset pancreatic cancer: A controlled trial. Ann. Gastroenterol. 2011, 24, 206-212. [PubMed]

6. Australian Institute of Health and Welfere; Australasian Association of Cancer Registries. Cancer in Australia: An Overview 2012; Australian Institute of Health and Welfare: Canberra, Australia, 2012.

7. Gordon, E.M.; Lopez, F.F.; Cornelio, G.H.; Lorenzo, C.C.; Levy, J.P.; Reed, R.A.; Liu, L.; Bruckner, H.W.; Hall, F.L. Pathotropic nanoparticles for cancer gene therapy Rexin-G $\mathrm{G}^{\mathrm{TM}} \mathrm{IV}$ : Three-year clinical experience. Int. J. Oncol. 2006, 29, 1053-1064. [CrossRef] [PubMed]

8. Hosein, P.J.; de Lima Lopes, G., Jr.; Pastorini, V.H.; Gomez, C.; Macintyre, J.; Zayas, G.; Reis, I.; Montero, A.J.; Merchan, J.R.; Rocha Lima, C.M. A phase II trial of nab-paclitaxel as second-line therapy in patients with advanced pancreatic cancer. Am. J. Clin. Oncol. 2013, 36, 151-156. [CrossRef] [PubMed]

9. Yu, X.; Zhang, Y.; Chen, C.; Yao, Q.; Li, M. Targeted drug delivery in pancreatic cancer. Biochim. Biophys. Acta 2010, 1805, 97-104. [CrossRef] [PubMed]

10. Shaib, Y.H.; Davila, J.A.; El-Serag, H.B. The epidemiology of pancreatic cancer in the united states: Changes below the surface. Aliment. Pharmacol. Ther. 2006, 24, 87-94. [CrossRef] [PubMed]

11. Oberstein, P.E.; Olive, K.P. Pancreatic cancer: Why is it so hard to treat? Ther. Adv. Gastroenterol. 2013, 6, 321-337. [CrossRef] [PubMed] 
12. Buzea, C.; Pacheco, I.I.; Robbie, K. Nanomaterials and nanoparticles: Sources and toxicity. Biointerphases 2007, 2. [CrossRef]

13. Jain, K. Advances in the field of nanooncology. BMC Med. 2010, 8. [CrossRef] [PubMed]

14. Malekigorji, M.; Curtis, A.; Hoskins, C. The use of iron oxide nanoparticles for pancreatic cancer therapy. J. Nanomed. Res. 2014, 1. [CrossRef]

15. Kunjachan, S.; Pola, R.; Gremse, F.; Theek, B.; Ehling, J.; Moeckel, D.; Hermanns-Sachweh, B.; Pechar, M.; Ulbrich, K.; Hennink, W.E.; et al. Passive versus active tumor targeting using RGD- and NGR-modified polymeric nanomedicines. Nano Lett. 2014, 14, 972-981. [CrossRef] [PubMed]

16. Sharma, A.; Madhunapantula, S.V.; Robertson, G.P. Toxicological considerations when creating nanoparticle based drugs and drug delivery systems? Expert Opin. Drug Metab. Toxicol. 2012, 8, 47-69. [CrossRef] [PubMed]

17. Dokka, S.; Toledo, D.; Shi, X.; Castranova, V.; Rojanasakul, Y. Oxygen radical-mediated pulmonary toxicity induced by some cationic liposomes. Pharm. Res. 2000, 17, 521-525. [CrossRef] [PubMed]

18. Lv, H.; Zhang, S.; Wang, B.; Cui, S.; Yan, J. Toxicity of cationic lipids and cationic polymers in gene delivery. J. Control. Release 2006, 114, 100-109. [CrossRef] [PubMed]

19. Keelan, J.A. Nanotoxicology: Nanoparticles versus the placenta. Nat. Nanotechnol. 2011, 6, $263-264$. [CrossRef] [PubMed]

20. Chang, C. The immune effects of naturally occurring and synthetic nanoparticles. J. Autoimmun. 2010, 34, J234-J246. [CrossRef] [PubMed]

21. Laurent, S.; Mahmoudi, M. Superparamagnetic iron oxide nanoparticles: Promises for diagnosis and treatment of cancer. Int. J. Mol. Epidemiol. Genet. 2011, 2, 367-390. [PubMed]

22. Wang, C.; Zhang, H.; Chen, B.; Yin, H.; Wang, W. Study of the enhanced anticancer efficacy of gambogic acid on Capan-1 pancreatic cancer cells when mediated via magnetic $\mathrm{Fe}_{3} \mathrm{O}_{4}$ nanoparticles. Int. J. Nanomed. 2011, 6, 1929-1935.

23. Papa, A.-L.; Basu, S.; Sengupta, P.; Banerjee, D.; Sengupta, S.; Harfouche, R. Mechanistic studies of gemcitabine-loaded nanoplatforms in resistant pancreatic cancer cells. BMC Cancer 2012, 12. [CrossRef] [PubMed]

24. Gannon, C.J.; Patra, C.R.; Bhattacharya, R.; Mukherjee, P.; Curley, S.A. Intracellular gold nanoparticles enhance non-invasive radiofrequency thermal destruction of human gastrointestinal cancer cells. J. Nanobiotechnol. 2008, 6. [CrossRef] [PubMed]

25. Ristorcelli, E.; Beraud, E.; Verrando, P.; Villard, C.; Lafitte, D.; Sbarra, V.; Lombardo, D.; Verine, A. Human tumor nanoparticles induce apoptosis of pancreatic cancer cells. FASEB J. 2008, 22, 3358-3369. [CrossRef] [PubMed]

26. Kudgus, R.A.; Szabolcs, A.; Khan, J.A.; Walden, C.A.; Reid, J.M.; Robertson, J.D.; Bhattacharya, R.; Mukherjee, P. Inhibiting the growth of pancreatic adenocarcinoma in vitro and in vivo through targeted treatment with designer gold nanotherapeutics. PLoS ONE 2013, 8, e57522. [CrossRef] [PubMed]

27. Lu, J.; Liong, M.; Zink, J.I.; Tamanoi, F. Mesoporous silica nanoparticles as a delivery system for hydrophobic anticancer drugs. Small 2007, 3, 1341-1346. [CrossRef] [PubMed]

28. Yoshida, M.; Takimoto, R.; Murase, K.; Sato, Y.; Hirakawa, M.; Tamura, F.; Sato, T.; Iyama, S.; Osuga, T.; Miyanishi, K. Targeting anticancer drug delivery to pancreatic cancer cells using a fucose-bound nanoparticle approach. PLoS ONE 2012, 7, e39545. [CrossRef] [PubMed]

29. Patra, C.R.; Bhattacharya, R.; Wang, E.; Katarya, A.; Lau, J.S.; Dutta, S.; Muders, M.; Wang, S.; Buhrow, S.A.; Safgren, S.L. Targeted delivery of gemcitabine to pancreatic adenocarcinoma using cetuximab as a targeting agent. Cancer Res. 2008, 68, 1970-1978. [CrossRef] [PubMed]

30. Glazer, E.S.; Zhu, C.; Massey, K.L.; Thompson, C.S.; Kaluarachchi, W.D.; Hamir, A.N.; Curley, S.A. Noninvasive radiofrequency field destruction of pancreatic adenocarcinoma xenografts treated with targeted gold nanoparticles. Clin. Cancer Res. 2010, 16, 5712-5721. [CrossRef] [PubMed]

31. Frese, K.K.; Neesse, A.; Cook, N.; Bapiro, T.E.; Lolkema, M.P.; Jodrell, D.I.; Tuveson, D.A. Nab-paclitaxel potentiates gemcitabine activity by reducing cytidine deaminase levels in a mouse model of pancreatic cancer. Cancer Discov. 2012, 2, 260-269. [CrossRef] [PubMed]

32. Khan, J.A.; Kudgus, R.A.; Szabolcs, A.; Dutta, S.; Wang, E.; Cao, S.; Curran, G.L.; Shah, V.; Curley, S.; Mukhopadhyay, D. Designing nanoconjugates to effectively target pancreatic cancer cells in vitro and in vivo. PLoS ONE 2011, 6, e20347. [CrossRef] [PubMed] 
33. Batist, G.; Gelmon, K.A.; Chi, K.N.; Miller, W.H.; Chia, S.K.; Mayer, L.D.; Swenson, C.E.; Janoff, A.S.; Louie, A.C. Safety, pharmacokinetics, and efficacy of CPX-1 liposome injection in patients with advanced solid tumors. Clin. Cancer Res. 2009, 15, 692-700. [CrossRef] [PubMed]

34. Seymour, L.W.; Ferry, D.R.; Kerr, D.J.; Rea, D.; Whitlock, M.; Poyner, R.; Boivin, C.; Hesslewood, S.; Twelves, C.; Blackie, R. Phase II studies of polymer-doxorubicin (PK1, FCE28068) in the treatment of breast, lung and colorectal cancer. Int. J. Oncol. 2009, 34, 1629-1636. [CrossRef] [PubMed]

35. Matsumura, Y.; Gotoh, M.; Muro, K.; Yamada, Y.; Shirao, K.; Shimada, Y.; Okuwa, M.; Matsumoto, S.; Miyata, Y.; Ohkura, H. Phase I and pharmacokinetic study of MCC-465, a doxorubicin (DXR) encapsulated in peg immunoliposome, in patients with metastatic stomach cancer. Ann. Oncol. 2004, 15, 517-525. [CrossRef] [PubMed]

36. Gradishar, W. Superior efficacy of albumin-bound paclitaxel, ABI-007, compared with polythylated castor oil-based pclitaxel in women with metastatic breast cancer: Results of a phase III trial. J. Clin. Oncol. 2005, 23, 5983-5992. [CrossRef] [PubMed]

37. Valle, J.W.; Armstrong, A.; Newman, C.; Alakhov, V.; Pietrzynski, G.; Brewer, J.; Campbell, S.; Corrie, P.; Rowinsky, E.K.; Ranson, M. A phase 2 study of SP1049C, doxorubicin in P-glycoprotein-targeting pluronics, in patients with advanced adenocarcinoma of the esophagus and gastroesophageal junction. Investig. New Drugs 2011, 29, 1029-1037. [CrossRef] [PubMed]

38. Liberatti, A.; Altman, D.G.; Tetzlaff, J.; Mulrow, C.; Gøtzsche, P.; Ioannidis, J. The PRISMA statement for reporting systematic review and meta-analysis of studies that evaluate healthcare interventions: Explanation and elaboration. Ann. Intern. Med. 2009, 151. [CrossRef]

39. Halpern, S.H.; Joanne Douglas, M. Jadad scale for reporting randomized controlled trials. In Evidence-Based Obstetric Anesthesia; Halpern, S.H., Joanne Douglas, M., Eds.; Blackwell Publishing: Malden, MA, USA, 2005; pp. 237-238.

40. Centre for Evidence-Based Medicine. Therapy Critical Appraisal Worksheet. Canadian Institute of Health Research. Available online: http://ktclearinghouse.ca/cebm/teaching/worksheets/therapy (accessed on 30 March 2015).

41. Von Hoff, D.D.; Ervin, T.; Arena, F.P.; Chiorean, E.G.; Infante, J.; Moore, M.; Seay, T.; Tjulandin, S.A.; Ma, W.W.; Saleh, M.N. Increased survival in pancreatic cancer with nab-paclitaxel plus gemcitabine. N. Engl. J. Med. 2013, 369, 1691-1703. [CrossRef] [PubMed]

42. Von Hoff, D.D.; Ramanathan, R.K.; Borad, M.J.; Laheru, D.A.; Smith, L.S.; Wood, T.E.; Korn, R.L.; Desai, N.; Trieu, V.; Iglesias, J.L. Gemcitabine plus nab-paclitaxel is an active regimen in patients with advanced pancreatic cancer: A phase I/II trial. J. Clin. Oncol. 2011, 29, 4548-4554. [CrossRef] [PubMed]

43. Gordon, E.M.; Cornelio, G.H.; Lorenzo, C.C.; Levy, J.P.; Reed, R.A.; Liu, L.; Hall, F.L. First clinical experience using a 'pathotropic' injectable retroviral vector (Rexin-G) as intervention for stage IV pancreatic cancer. Int. J. Oncol. 2004, 24, 177-185. [CrossRef] [PubMed]

44. Hamaguchi, T.; Kato, K.; Yasui, H.; Morizane, C.; Ikeda, M.; Ueno, H.; Muro, K.; Yamada, Y.; Okusaka, T.; Shirao, K. A phase I and pharmacokinetic study of NK105, a paclitaxel-incorporating micellar nanoparticle formulation. Br. J. Cancer 2007, 97, 170-176. [CrossRef] [PubMed]

45. Stathopoulos, G.P.; Boulikas, T.; Vougiouka, M.; Rigatos, S.K.; Stathopoulos, J.G. Liposomal cisplatin combined with gemcitabine in pretreated advanced pancreatic cancer patients: A phase I-II study. Oncol. Rep. 2006, 15, 1201-1204. [CrossRef] [PubMed]

46. Libutti, S.K.; Paciotti, G.F.; Byrnes, A.A.; Alexander, H.R.; Gannon, W.E.; Walker, M.; Seidel, G.D.; Yuldasheva, N.; Tamarkin, L. Phase I and pharmacokinetic studies of CYT-6091, a novel PEGylated colloidal gold-rhTNF nanomedicine. Clin. Cancer Res. 2010, 16, 6139-6149. [CrossRef] [PubMed]

47. Galanis, E.; Carlson, S.K.; Foster, N.R.; Lowe, V.; Quevedo, F.; McWilliams, R.R.; Grothey, A.; Jatoi, A.; Alberts, S.R.; Rubin, J. Phase I trial of a pathotropic retroviral vector expressing a cytocidal cyclin G1 construct (Rexin-G) in patients with advanced pancreatic cancer. Mol. Ther. 2008, 16, 979-984. [CrossRef] [PubMed]

48. Chawla, S.P.; Chua, V.S.; Fernandez, L.; Quon, D.; Blackwelder, W.C.; Gordon, E.M.; Hall, F.L. Advanced phase I/II studies of targeted gene delivery in vivo: Intravenous Rexin-G for gemcitabine-resistant metastatic pancreatic cancer. Mol. Ther. 2010, 18, 435-441. [CrossRef] [PubMed]

49. Kratz, F. Albumin as a drug carrier: Design of prodrugs, drug conjugates and nanoparticles. J. Control. Release 2008, 132, 171-183. [CrossRef] [PubMed] 
50. Torchilin, V.P. Multifunctional nanocarriers. Adv. Drug Deliv. Rev. 2006, 58, 1532-1555. [CrossRef] [PubMed]

51. Stathopoulos, G.P.; Boulikas, T.; Vougiouka, M.; Deliconstantinos, G.; Rigatos, S.; Darli, E.; Viliotou, V.; Stathopoulos, J.G. Pharmacokinetics and adverse reactions of a new liposomal cisplatin (lipoplatin): Phase I study. Oncol. Rep. 2005, 13, 589-595. [CrossRef] [PubMed]

52. Berlin, J.D.; Catalano, P.; Thomas, J.P.; Kugler, J.W.; Haller, D.G. Phase III study of gemcitabine in combination with fluorouracil versus gemcitabine alone in patients with advanced pancreatic carcinoma: Eastern cooperative oncology group trial E2297. J. Clin. Oncol. 2002, 20, 3270-3275. [CrossRef] [PubMed]

53. Lima, C.M.R.; Green, M.R.; Rotche, R.; Miller, W.H.; Jeffrey, G.M.; Cisar, L.A.; Morganti, A.; Orlando, N.; Gruia, G.; Miller, L.L. Irinotecan plus gemcitabine results in no survival advantage compared with gemcitabine monotherapy in patients with locally advanced or metastatic pancreatic cancer despite increased tumor response rate. J. Clin. Oncol. 2004, 22, 3776-3783. [CrossRef] [PubMed]

54. Louvet, C.; Labianca, R.; Hammel, P.; Lledo, G.; De Braud, F.; Andre, T.; Cantore, M.; Ducreux, M.; Zaniboni, A.; De Gramont, A. GemOx (Gemcitabine + Oxaliplatin) versus Gem (Gemcitabine) in non resectable pancreatic adenocarcinoma: Final results of the GERCOR/GISCAD intergroup phase III. In Proceedings of the ASCO Annual Meeting, New Orleans, LA, USA, 5-8 June 2004; p. 4008.

55. Oettle, H.; Richards, D.; Ramanathan, R.; van Laethem, J.; Peeters, M. A randomized phase III study comparing gemcitabine pemetrexed versus gemcitabine in patients with locally advanced and metastatic pancreas cancer. Ann. Oncol. 2005, 16, 1639-1645. [CrossRef] [PubMed]

56. Abou-Alfa, G.K.; Letourneau, R.; Harker, G.; Modiano, M.; Hurwitz, H.; Tchekmedyian, N.S.; Feit, K.; Ackerman, J.; De Jager, R.L.; Eckhardt, S.G.; et al. Randomized phase III study of exatecan and gemcitabine compared with gemcitabine alone in untreated advanced pancreatic cancer. J. Clin. Oncol. 2006, 24, 4441-4447. [CrossRef] [PubMed]

57. Poplin, E.; Levy, D.; Berlin, J.; Rothenberg, M.; O’Dwyer, P.; Cella, D. Phase III trial of gemcitabine (30-min infusion) versus gemcitabine (fixed-dose rate infusion) versus gemcitabine plus oxaliplatin (GEMOX) in patients with advanced pancreatic cancer. J. Clin. Oncol. 2006, 24, 933 s.

58. Van Cutsem, E.; van de Velde, H.; Karasek, P.; Oettle, H.; Vervenne, W.; Szawlowski, A.; Schoffski, P.; Post, S.; Verslype, C.; Neumann, H. Phase III trial of gemcitabine plus tipifarnib compared with gemcitabine plus placebo in advanced pancreatic cancer. J. Clin. Oncol. 2004, 22, 1430-1438. [CrossRef] [PubMed]

59. Bramhall, S.; Schulz, J.; Nemunaitis, J.; Brown, P.; Baillet, M.; Buckels, J. A double-blind placebo-controlled, randomised study comparing gemcitabine and marimastat with gemcitabine and placebo as first line therapy in patients with advanced pancreatic cancer. Br. J. Cancer 2002, 87, 161-167. [CrossRef] [PubMed]

60. Watson, S.A.; Gilliam, A.D. G17DT-A new weapon in the therapeutic armoury for gastrointestinal malignancy. Expert Opin. Biol. Ther. 2001, 1, 309-317. [CrossRef] [PubMed]

61. Moore, M.J.; Goldstein, D.; Hamm, J.; Figer, A.; Hecht, J.R.; Gallinger, S.; Au, H.J.; Murawa, P.; Walde, D.; Wolff, R.A. Erlotinib plus gemcitabine compared with gemcitabine alone in patients with advanced pancreatic cancer: A phase III trial of the national cancer institute of Canada clinical trials group. J. Clin. Oncol. 2007, 25, 1960-1966. [CrossRef] [PubMed]

62. Graham-Bonnalie, F.E. Gold for rheumatoid arthritis. Br. Med. J. 1971, 2, 277. [CrossRef] [PubMed]

63. Myer, L.; Jones, D.; Tamarkin, L.; Paciotti, G. Nanomedicine-based enhancement of chemotherapy. Cancer Res. 2008, 68, 5718.

64. Meng, H.; Mai, W.X.; Zhang, H.; Xue, M.; Xia, T.; Lin, S.; Wang, X.; Zhao, Y.; Ji, Z.; Zink, J.I.; et al. Codelivery of an optimal drug/sirna combination using mesoporous silica nanoparticles to overcome drug resistance in breast cancer in vitro and in vivo. ACS Nano 2013, 7, 994-1005. [CrossRef] [PubMed]

65. Meng, H.; Wang, M.; Liu, H.; Liu, X.; Situ, A.; Wu, B.; Ji, Z.; Chang, C.H.; Nel, A.E. Use of a lipid-coated mesoporous silica nanoparticle platform for synergistic gemcitabine and paclitaxel delivery to human pancreatic cancer in mice. ACS Nano 2015, 9, 3540-3557. [CrossRef] [PubMed]

66. Ferrari, M. Cancer nanotechnology: Opportunities and challenges. Nat. Rev. Cancer 2005, 5, $161-171$. [CrossRef] [PubMed]

67. McCarroll, J.; Teo, J.; Boyer, C.; Goldstein, D.; Kavallaris, M.; Phillips, P.A. Potential applications of nanotechnology for the diagnosis and treatment of pancreatic cancer. Front. Physiol. 2014, 5. [CrossRef] [PubMed]

68. Singh, S.; Sharma, A.; Robertson, G.P. Realizing the clinical potential of cancer nanotechnology by minimizing toxicologic and targeted delivery concerns. Cancer Res. 2012, 72, 5663-5668. [CrossRef] [PubMed] 
69. Schroeder, A.; Heller, D.A.; Winslow, M.M.; Dahlman, J.E.; Pratt, G.W.; Langer, R.; Jacks, T.; Anderson, D.G. Treating metastatic cancer with nanotechnology. Nat. Rev. Cancer 2012, 12, 39-50. [CrossRef] [PubMed]

70. Namiki, Y.; Fuchigami, T.; Tada, N.; Kawamura, R.; Matsunuma, S.; Kitamoto, Y.; Nakagawa, M. Nanomedicine for cancer: Lipid-based nanostructures for drug delivery and monitoring. Acc. Chem. Res. 2011, 44, 1080-1093. [CrossRef] [PubMed]

71. Blanco, E.; Hsiao, A.; Mann, A.P.; Landry, M.G.; Meric-Bernstam, F.; Ferrari, M. Nanomedicine in cancer therapy: Innovative trends and prospects. Cancer Sci. 2011, 102, 1247-1252. [CrossRef] [PubMed]

72. Robertson, C.A.; Evans, D.H.; Abrahamse, H. Photodynamic therapy (PDT): A short review on cellular mechanisms and cancer research applications for PDT. J. Photochem. Photobiol. B 2009, 96, 1-8. [CrossRef] [PubMed]

73. Piktel, E.; Niemirowicz, K.; Wątek, M.; Wollny, T.; Deptuła, P.; Bucki, R. Recent insights in nanotechnology-based drugs and formulations designed for effective anti-cancer therapy. J. Nanobiotechnol. 2016, 14, 1-23. [CrossRef] [PubMed]

74. Han, J.; Li, J.; Jia, W.; Yao, L.; Li, X.; Jiang, L.; Tian, Y. Photothermal therapy of cancer cells using novel hollow gold nanoflowers. Int. J. Nanomed. 2014, 9, 517-526.

75. Fan, Z.; Dai, X.; Lu, Y.; Yu, E.; Brahmbatt, N.; Carter, N.; Tchouwou, C.; Singh, A.K.; Jones, Y.; Yu, H.; et al. Enhancing targeted tumor treatment by near IR light-activatable photodynamic-photothermal synergistic therapy. Mol. Pharm. 2014, 11, 1109-1116. [CrossRef] [PubMed]

76. Hainfeld, J.F.; Dilmanian, F.A.; Slatkin, D.N.; Smilowitz, H.M. Radiotherapy enhancement with gold nanoparticles. J. Pharm. Pharmacol. 2008, 60, 977-985. [CrossRef] [PubMed]

77. Townley, H.E.; Kim, J.; Dobson, P.J. In vivo demonstration of enhanced radiotherapy using rare earth doped titania nanoparticles. Nanoscale 2012, 4, 5043-5050. [CrossRef] [PubMed]

78. Le Duc, G.; Miladi, I.; Alric, C.; Mowat, P.; Bräuer-Krisch, E.; Bouchet, A.; Khalil, E.; Billotey, C.; Janier, M.; Lux, F; et al. Toward an image-guided microbeam radiation therapy using gadolinium-based nanoparticles. ACS Nano 2011, 5, 9566-9574. [CrossRef] [PubMed]

79. Deer, E.L.; González-Hernández, J.; Coursen, J.D.; Shea, J.E.; Ngatia, J.; Scaife, C.L.; Firpo, M.A.; Mulvihill, S.J. Phenotype and genotype of pancreatic cancer cell lines. Pancreas 2010, 39, 425-435. [CrossRef] [PubMed]

80. Eibl, G.; Bruemmer, D.; Okada, Y.; Duffy, J.P.; Law, R.E.; Reber, H.A.; Hines, O.J. PGE 2 is generated by specific COX-2 activity and increases VEGF production in COX-2-expressing human pancreatic cancer cells. Biochem. Biophys. Res. Commun. 2003, 306, 887-897. [CrossRef]

81. Eibl, G.; Reber, H.A.; Wente, M.N.; Hines, O.J. The selective cyclooxygenase-2 inhibitor nimesulide induces apoptosis in pancreatic cancer cells independent of COX-2. Pancreas 2003, 26, 33-41. [CrossRef] [PubMed]

82. Molina, M.A.; Sitja-Arnau, M.; Lemoine, M.G.; Frazier, M.L.; Sinicrope, F.A. Increased cyclooxygenase-2 expression in human pancreatic carcinomas and cell lines growth inhibition by nonsteroidal anti-inflammatory drugs. Cancer Res. 1999, 59, 4356-4362. [PubMed]

83. Yip-Schneider, M.T.; Sweeney, C.J.; Jung, S.-H.; Crowell, P.L.; Marshall, M.S. Cell cycle effects of nonsteroidal anti-inflammatory drugs and enhanced growth inhibition in combination with gemcitabine in pancreatic carcinoma cells. J. Pharmacol. Exp. Ther. 2001, 298, 976-985. [PubMed]

(C) 2016 by the authors; licensee MDPI, Basel, Switzerland. This article is an open access article distributed under the terms and conditions of the Creative Commons Attribution (CC-BY) license (http://creativecommons.org/licenses/by/4.0/). 